\title{
About problems with cast iron columns of the revitalized post-industrial buildings
}

\author{
Tadeusz Urban ${ }^{1}$, and Michat Gołdyn ${ }^{1, *}$ \\ ${ }^{1}$ Lodz University of Technology, Department of Concrete Structures, al. Politechniki 6, Łódź, Poland
}

\begin{abstract}
The paper discusses examples of the use of cast iron columns in existing post-industrial buildings. The results of experimental investigations in which a cast iron column originating from an existing structure was subjected to compression, were presented. The load carrying capacity of the element was assessed in the light of historical design procedures, demonstrating their conservativeness resulting from material uncertainties. The examples of failures of cast iron columns, resulting from errors committed during modernization works, were also presented.
\end{abstract}

\section{A short presentation of the problem}

The turn of the 18th and 19th centuries was the beginning of the industrial revolution. The rapid industrialization required the construction of new buildings of unprecedented previously size. Initially, the ceilings of multi-storey industrial and warehouse buildings were made as wooden, based on masonry walls and additionally supported by two or three rows of columns. An important disadvantage of this type of structure was the lack of fire resistance. The storage of flammable materials such as cotton in conjunction with oil vapours used to lubricate moving machine parts and the use of open flame lighting lamps created conditions conducive to the rapid emergence of a fire. The destructive effects of fire, as well as the pressure from the insurance companies, provided an incentive for seeking fire resistant solutions. Initial attempts to cover wooden elements with steel plate and plastering mortar were eventually finished by elimination or significant reduction the use of wood. In place of wooden beams and columns, cast iron elements were introduced. In 1789, English engineer William Jessop patented the shape of a cast-iron beam in the form of a fish-belly, which referred to the course of bending moments in a simply supported beam.

In Polish lands, the development of industrial structures took place with a certain delay to the leading then England. The beginnings of dynamic industrialisation of Łódź took place during the Kingdom of Poland, when the first masonry industrial facilities were built.

Buildings constructed in Łódź in the second half of the 19th century, following the dynamic development of the textile industry, fulfilled their function without major changes until the end of the 1980s. As a result of socio-economic transformation, the majority of large textile factories collapsed, which resulted in the problem of developing hundreds of postindustrial buildings, often characterized by high architectural values. The only chance for preserving these buildings is revitalization, consisting in adaptation to new functions with the

* Corresponding author: michal.goldyn@p.lodz.p1 
preservation of the original structure as much as possible. The most spectacular and successful examples of revitalization of the largest industrial complexes in Łódź can be the former Poznański Cotton Factory (now the Manufaktura shopping center) and the complex of textile factories at Księży Młyn (currently lofts "U Scheiblera"). In the Figure 1 the examples of the preservation of 19th century structural elements and their adaptation to contemporary function are presented.

a)

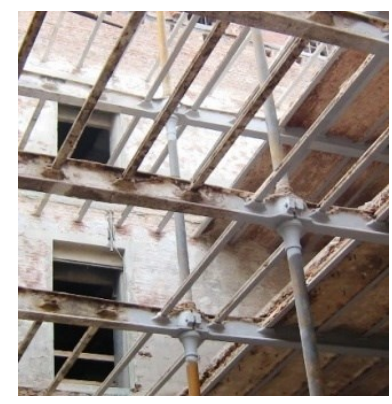

b)

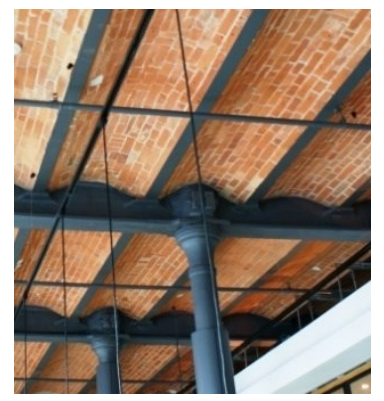

c)

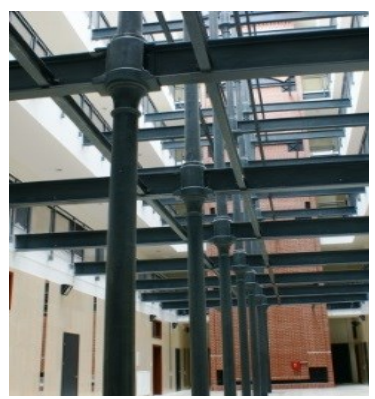

Fig. 1. A cast iron and steel skeleton in the former spinning mill buildings: a) during adaptation works, b) after the completion of works - the ceiling in Andel's hotel, c) structure in the lofts "U Scheiblera".

One of the technical problems of revitalisation is the assessment of the load carrying capacity of the existing cast iron columns. The lack of the contemporary standard regulations concerning design of cast iron structures proves a significant problem during expert works. The aim of the paper is to fill partially the gap in this area. For this reason the historical principles of designing of cast-iron elements, which were used in Europe during the erection of currently revitalized objects, will be presented.

At present, the third of large industrial complexes is being revitalized in Łódź. It is Monopol Wódczany (The Vodka Monopoly) built in 1902 and functioned in the post-war period as Zakłady Przemysłu Spirytusowego Polmos Łódź. The greatest development of these facilities took place at the end of the 1970 s, when the monthly production was one million half-liter bottles of pure and quality vodkas. The production was stopped in April 2007, while in 2013, as a result of ownership changes, a new era of this one of the most valuable monuments in Lódź (currently known as Monopolis), began. In the Figure 2 a fragment of the main bearing structure of the post-industrial building was presented.

a)

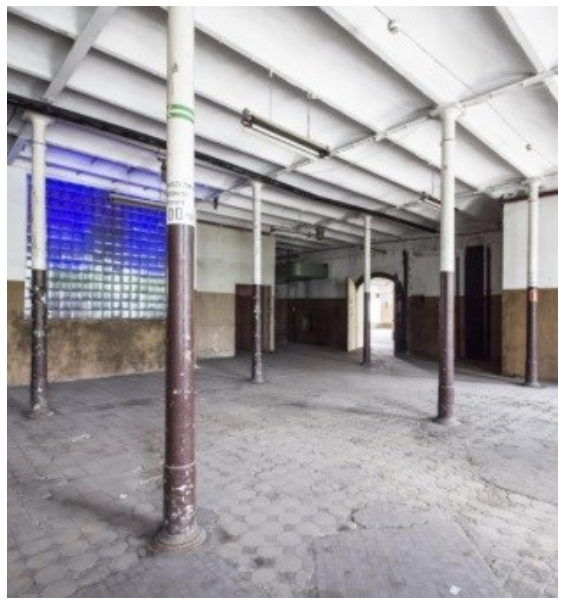

b)

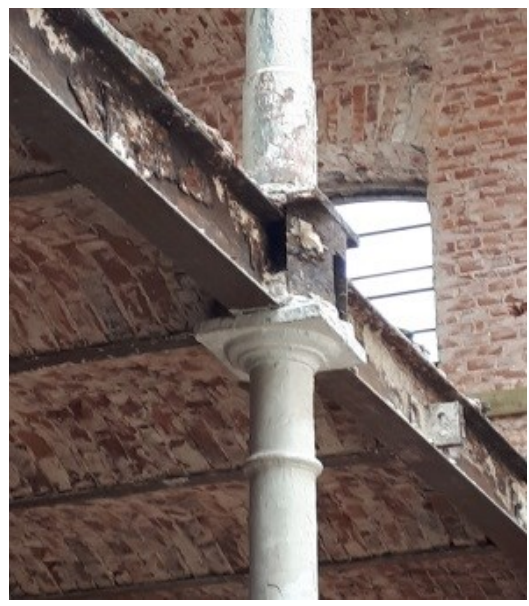

Fig. 2. Cast-iron columns in the building of the former Monopol Wódczany plants currently being transformed into the Monopolis office, service and cultural complex. 


\section{Cast iron as structural material}

Gray cast iron is a type of iron-carbon casting alloy in which unbound carbon occurs as graphite, mainly in the form of flakes. It should be borne in mind that the properties of cast iron were very diverse at the turn of the 19th and 20th centuries and were not regulated by any standard provisions. The existing standard PN-EN 1561 [1] only deals with casting issues and can be helpful by determining the methods of testing the mechanical properties of cast iron. The monograph by Czapliński [2] is a particularly valuable literature item, which summarizes and includes information about structural iron, taken from various design provisions from the late 19th and first half of the 20th century - see Table 1.

Table 1. Permissible stress $\sigma_{\text {dop }}$ (in MPa) for cast iron structural elements, according to [2]

\begin{tabular}{|l|c|c|c|c|c|c|c|c|}
\hline Type of stress & $1871^{1}$ & $1879^{2}$ & $1904^{3}$ & $1920^{4}$ & $1921^{5}$ & $1925^{6}$ & $1934^{7}$ & $1937^{8}$ \\
\hline compression & 50 & 90 & 80 & 50 & 80 & 60 & 90 & 90 \\
\hline tension & 25 & 30 & - & 25 & - & 25 & - & 30 \\
\hline bending & - & $43 \div 62$ & - & 30 & 30 & - & - & - \\
\hline tension by bending & 25 & - & 30 & - & - & 30 & 45 & 30 \\
\hline shear & 20 & 30 & - & 25 & - & 25 & - & - \\
\hline $\begin{array}{l}1 \\
2\end{array}$ & Bauordnung der Stadt Berlin, 1871, \\
& $\begin{array}{l}\text { Bach C.: Elastigkeit, 1889, } \\
\text { Aufestellung des Österreichische Normenausschusses für Strassenbrücken, August 1921, }\end{array}$ \\
4 \\
Regulation of the Minister of Public Works from 4 March 1920, \\
Regulation of the Minister of Public Works of Czechoslovak Republic from April 1921, \\
6 \\
Bauordnung Für Volkswohlfahrt. Zentralbatt der Bauverwaltung, 1925, \\
7 DIN 1051, 1934, \\
8 DIN 1051, 1937.
\end{tabular}

The extensive investigations of cast iron were carried out by Ludwig von Tetmajer [3] in the second half of the 19th century, who determined chemical composition of the irons used at that time:
- carbon (C)
$3.171 \div 3.264 \%$;
- silicon $(\mathrm{Si})$
$0.926 \div 1.136 \%$;
- phosphorus $(\mathrm{P})$
$0.164 \div 0.258 \%$;
- manganese (Mn)
$1.122 \div 1.655 \%$;
- $\operatorname{sulphur}(\mathrm{S})$
$0.050 \div 0.070 \%$.

Tetmajer found also the following strength characteristics of the cast iron:
- tensile strength
$R_{m}=125 \mathrm{MPa}$.
- modulus of elasticity
$E=100 \mathrm{GPa}$.
- modulus of rigidity
$G=38 \mathrm{GPa}$.
- coefficient of thermal expansion
$\alpha_{t}=10^{-5} 1 / \mathrm{K}$. 


\section{Experimental investigations of cast iron column}

During revitalization of the building complex of the former Polmos Łódź factory at Kopcińskiego 58/60, it was necessary to assess the load carrying capacity of the existing structural elements. In particular, it concerned cast iron column, which were planned to be preserved. Due to the change in the way the object was used, the capacity of the columns had to be determined in order to allow a safe and rational estimation of the permissible floor load. For this reason in the Laboratory of the Department of Concrete Structures of the Lodz University of Technology, a destructive test of the cast iron column as well as accompanying tests of properties of cast iron, from which it was made, were carried out.

The tests were carried out in a test setup with a maximum pressure of $6000 \mathrm{kN}$. Due to the technical possibilities (clearance between the reaction beam and the base of the press) it was necessary to shorten the column by cutting off the head and the base. These parts were characterized by a much larger section than the rest of the column, therefore the mentioned procedure did not cause the weakening of the element.

The tensile strength was determined on the tests of three samples (on flat specimens for tensile tests and cylinders with a diameter of about $20 \mathrm{~mm}$ and a height of $40 \mathrm{~mm}$ for the compression test) made of material taken from the base of column. During the tests, some slight differences in the stress-strain curves as well as the maximum stress were found. They resulted from the inhomogeneity of the cast iron structure. Failure by compression test occurred in a manner characteristic for brittle material - by cleavage. The surface of failure was inclined at an angle of about $35^{\circ}$ to the axis of the sample. On the basis of tests, the following strength characteristics of the cast iron used for casting the considered column were determined:

- ultimate stress by axial compression: $\quad R_{c}=450.6 \mathrm{MPa}$,

- ultimate stress by axial tension:

$$
R_{t}=103.8 \mathrm{MPa} \text {. }
$$

The obtained ratio of compressive to tensile strength $R_{c} / R_{t}=4.34$ was characteristic for a brittle material. This value is slightly lower than the ratio $R_{c} / R_{t}=6$ conventionally assumed for typical $19^{\text {th }}$ century cast iron. Based on the strain measurements, a stress-strain diagram was made for the entire stress range - see Fig. 3. Due to the maximal measuring range of strain gauges, only measurements below $15 \%$ could be considered as reliable. However, by extrapolation, the maximum shortening at fracture $\varepsilon_{s, c}=33 \%$ was estimated. Considering only the range of elastic deformations, the secant modulus of elasticity was set equal to $115 \mathrm{GPa}$.

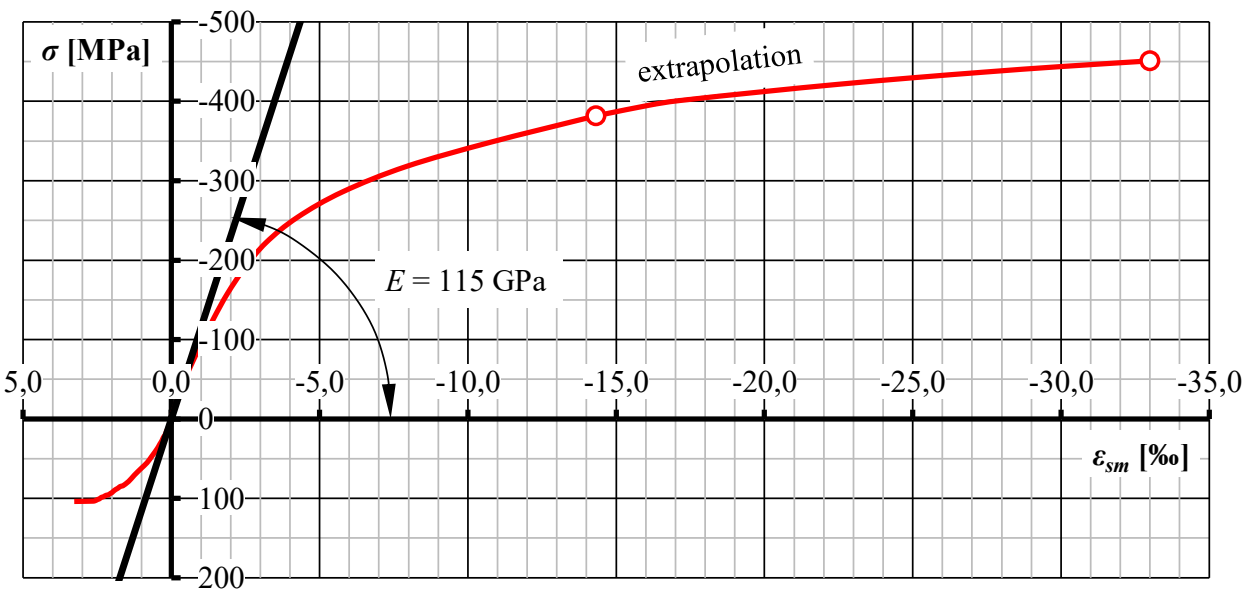

Fig. 3. Stress - strain relationship determined according to destructive tests. 
The subject of the main study was a cast iron column with a height of about $3,1 \mathrm{~m}$ and a non-prismatic section, gradually decreasing from the base towards the head. Due to the method of casting the element, the wall thickness was not constant around the perimeter. The extent of the actual diameter deviates from the idealized ring as evidenced by the measurements of the column wall thickness shown in Fig. 4. In the vicinity of the column head, it varied from $18.2 \div 24.0 \mathrm{~mm}$, while at the base it was $21.3 \div 29.6 \mathrm{~mm}$. The inner diameter was $119.9 \mathrm{~mm}$ and $133.1 \mathrm{~mm}$ at the head and at the column base respectively. Asymmetry of the cross-section resulted in low geometric eccentricities, accounting about $e=2.3 \div 3.5 \mathrm{~mm}$.

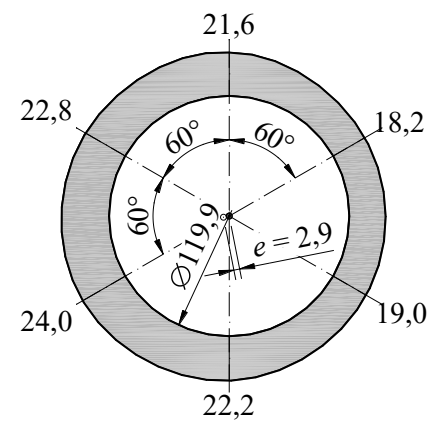

a)

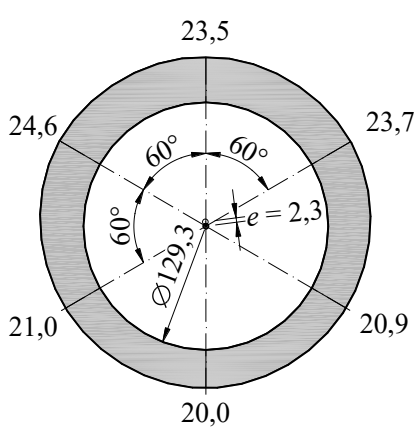

b)

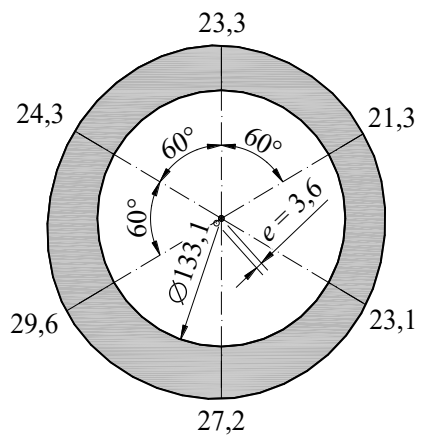

c)

Fig. 4. Cross section of the column at the distance of : a) $0.10 \mathrm{~m}$, b) $1.80 \mathrm{~m}$, c) $2.80 \mathrm{~m}$ from the base.

In the initial phase of the test, uniform shortening of the column related to loading was recorded. At about $70 \%$ of the destructive force that gradual deformation (bending) of the column was visible. Immediately before the failure the deflection of the column with respect to the original axis was a few millimeters. Failure was a result of the loss of stability (buckling) at a force equal to $F_{\max }=2605 \mathrm{kN}$. In the Figure 5 the column after folding from parts, in which was divided into as a result of the explosive destruction, was presented. It broke in three locations: at the base, in $2 / 3$ of its height and in the vicinity of the upper head.

The destruction was extremely violent and occurred within fractions of a second. This is clearly seen in the time-lapse analysis carried out after the test - see Fig. 6 . The failure was initiated by a crack formed in $2 / 3$ of the column's height (the place marked with a yellow arrow in Fig. 6). Immediately after the occurrence of the first crack, another one was observed adjacent to the column base. The energy released during the fracture was so high that fragments of a large size were found a few meters from the test setup. 


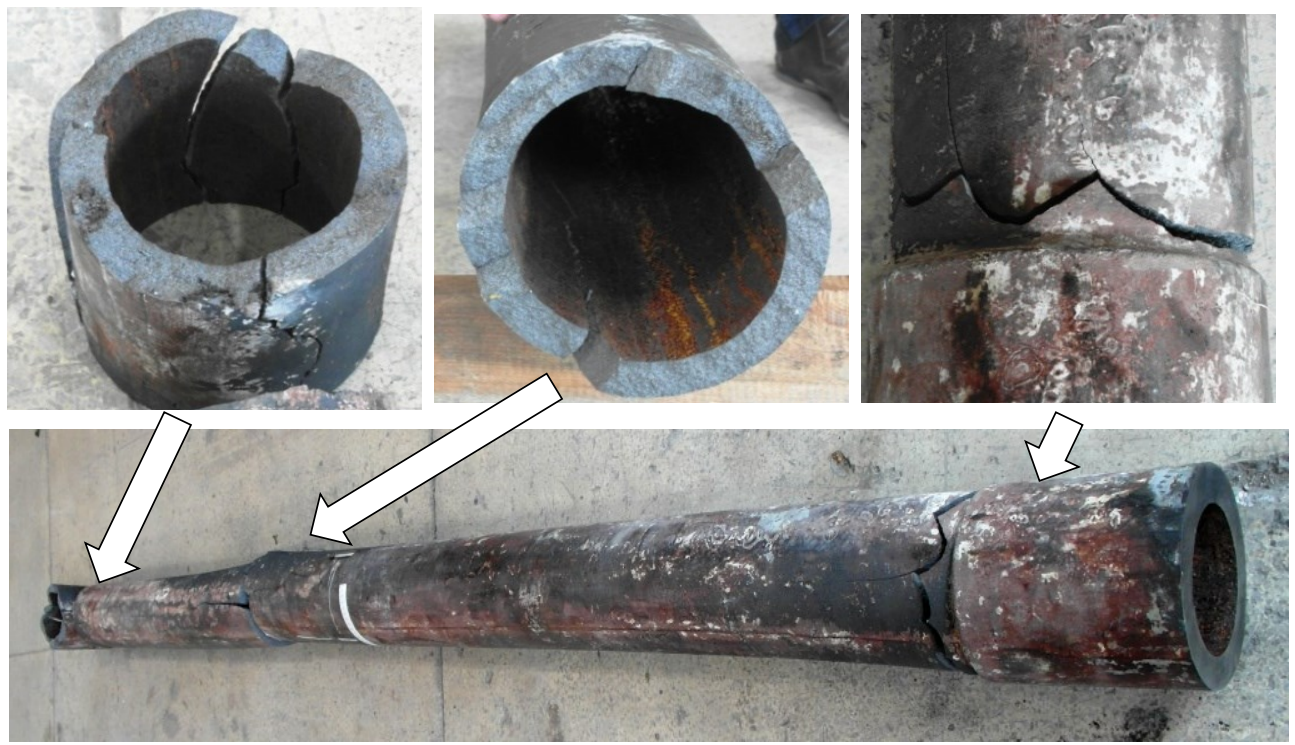

Fig. 5. View of the column after end of the test.
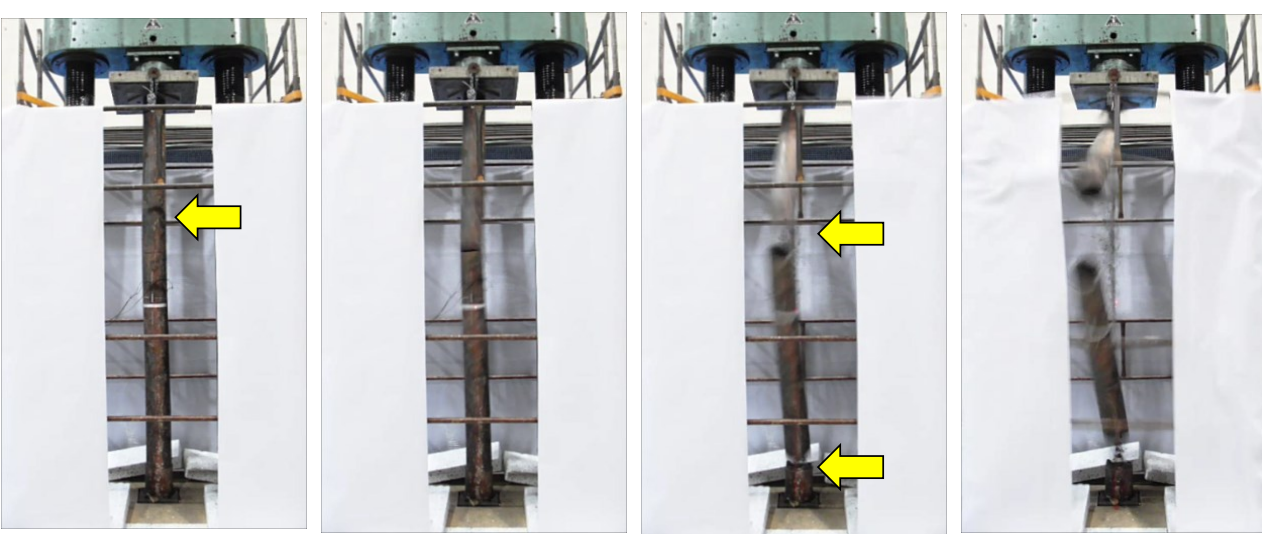

0

$0,03 \mathrm{~s}$.
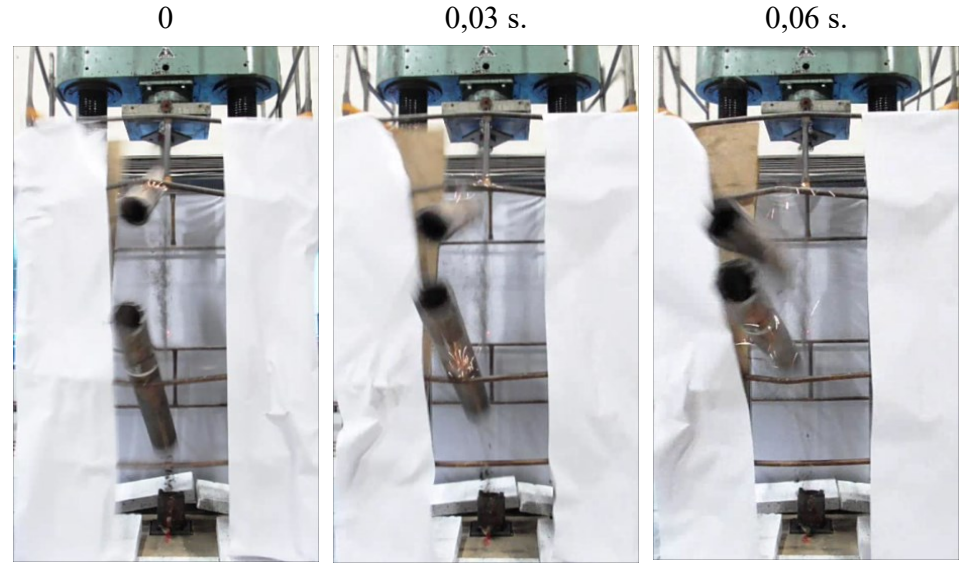

$0,24 \mathrm{~s}$.

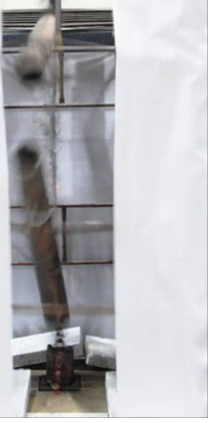

$0,09 \mathrm{~s}$.

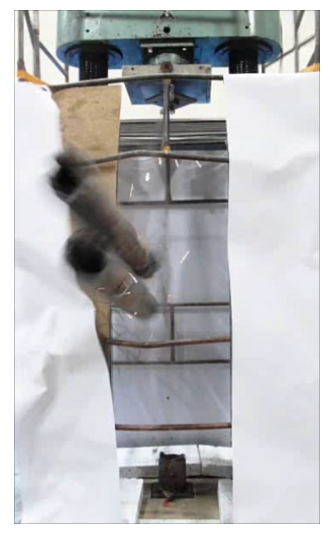

$0,30 \mathrm{~s}$.

Fig. 6. The course of column destruction - time measured from the moment of the first crack occurrence. 
During the test, deformations at half of the column height at three points spaced evenly around the perimeter were recorded - see Fig. 7. As a result of the column unloading in the first phase of the test, by a load of about $1400 \mathrm{kN}$, a permanent deformation of approximately $\Delta \varepsilon=0.20 \%$ occurred. Increasing the column load resulted in an even increase in deformation on all of the surfaces. At a load of about $2000 \mathrm{kN}$ (accounting for about $\sim 77 \%$ of the ultimate force), the average strain of the cross section was about $\varepsilon_{s m}=2.0 \%$ ("-" means compression). As the load was increased, a gradual decrease and then a change in the nature of the strains measured in the measuring base T3 was recorded. At the maximum load $F_{\max }=2605 \mathrm{kN}$, the deformations at the aforementioned place were close to zero $\left(\varepsilon_{s 3}=-0.3 \%\right.$ ), while at the moment preceding failure they amounted to $\varepsilon_{s 3}=1.65 \%$ (tension). This deformation was therefore about twice lower than the strain at rupture by tension test. The change in stress (from compression to tension) occurred only in the vicinity of the T3 base. In the other two measurement points, during the tests only compressive stresses were recorded. The maximum measured strains were about $-9.0 \%$ - much lower than the ultimate strains at fracture of the cylindrical samples $\left(\varepsilon_{s m}=-33 \%\right)$. The failure of the column was therefore a consequence of exceeding of the material strength on the tensioned side, due to deflection resulting from buckling and not from fracture of the iron in the compressed side of the cross section.

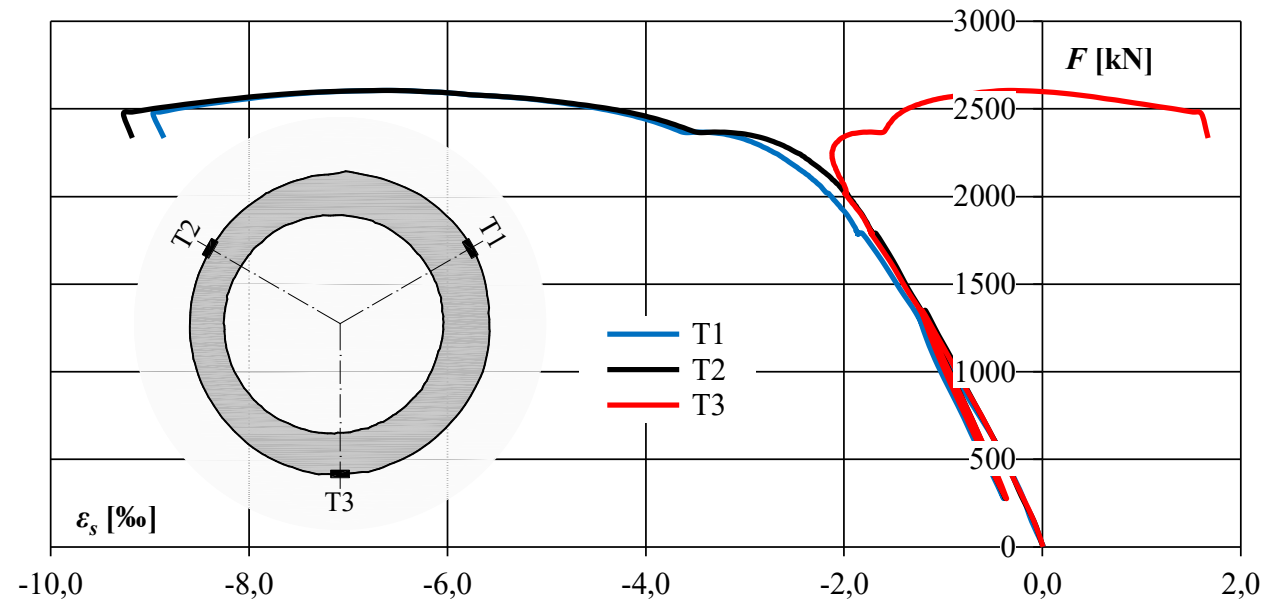

Fig. 7. The results of measurements at the half of the column height.

In the Figure 8 the distribution of stresses in the column cross section, according to the load level, was shown. At the ultimate load $F_{\max }$, the maximum tensile stresses were 7.5 times lower than the maximum compressive stresses in the cross section. Right before failure the maximum compressive stress was $330 \mathrm{MPa}$ while tensile stress $84 \mathrm{MPa}$, which constituted respectively: $73 \%$ of compressive strength and $81 \%$ of tensile strength. 


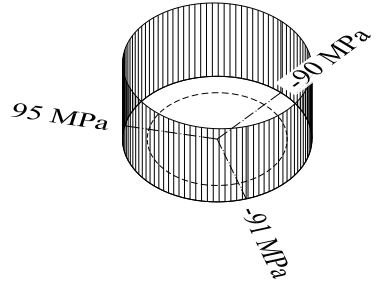

a)

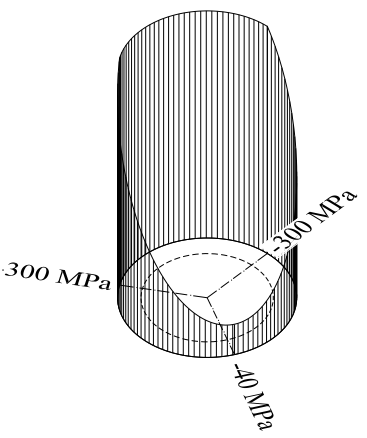

b)

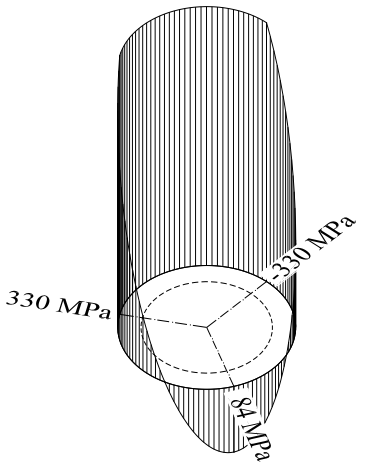

c)

Fig. 8. Distribution of the stress in the column cross section (at the half of the height) according to load level: a) $0.4 F_{\max }$, b) $F_{\max }$, c) at the moment preceding failure.

\section{Comparison between experimental and theoretical loads}

Contemporary standard regulations do not include guidelines for the design of cast iron elements. This is a significant obstacle by preparing of expert opinions and designs. It is therefore necessary to take into account the historical principles, which were in force in the first half of the $20^{\text {th }}$ century. In the years $1900-1937$, compressive stresses of $50 \div 90 \mathrm{MPa}$ and tensile stress of $25 \div 30 \mathrm{MPa}[4,5]$ were allowed for gray cast iron. On the basis of the extensive experimental studies, Tetmajer [3] proposed the following empirical expressions to determine critical stresses in compressed columns of a slenderness $\lambda$ (where: $n$-safety factor, equal to 10 ):

$$
\begin{aligned}
& \sigma_{k}=\frac{1}{n}\left(776-12 \lambda+0,055 \lambda^{2}\right) \quad[\mathrm{MPa}], \quad \text { if } \lambda \leq 80 \\
& \sigma_{k}=\frac{1}{n} \cdot \frac{987000}{\lambda^{2}} \quad[\mathrm{MPa}], \quad \text { if } \lambda>80
\end{aligned}
$$

In 1937 the following formulas for permissible critical stress related to the buckling of axially compressed cast iron columns were introduced in the DIN 1051 standard [3] :

$$
\begin{aligned}
& \sigma_{k}=\left(90-0,01005 \lambda^{2}\right) \quad[\mathrm{MPa}], \quad \text { if } \lambda \leq 80 \\
& \sigma_{k}=\frac{164500}{\lambda^{2}} \quad[\mathrm{MPa}], \quad \text { if } \lambda>80
\end{aligned}
$$

To calculate the theoretical load carrying capacity of the tested column, a cross section in $2 / 3$ of its height was assumed (corresponding to the location where the destruction was initiated). It was established that the cross-sectional area is equal to $A=10526 \mathrm{~mm}^{2}$, while the smallest radius of inertia $i_{2}=53.38 \mathrm{~mm}$. 
The slenderness of the column (assuming a prismatic cross section) was therefore approximately:

$$
\lambda=\frac{l_{0}}{i_{2}}=\frac{3100}{53,38} \approx 58,
$$

where $l_{0}$ is effective length of column, equal to its actual height.

By using the expressions (1) and (2) the critical stresses were calculated as $26.5 \mathrm{MPa}$ and $56.2 \mathrm{MPa}$ respectively. The design load carrying capacity according to Tetmajer [3] was therefore $279 \mathrm{kN}$, compared to $592 \mathrm{kN}$ in accordance with DIN 1051 [4]. The calculated design loads were therefore $4.4 \div 9.3$ times lower than the experimental ones. The indicated differences constitute a measure of distrust of $20^{\text {th }}$ century engineers against cast iron due to the uncertainties of material features.

\section{The examples of failures of cast iron column}

Adaptation of the existing cast iron columns may sometimes encounter significant difficulties. One of the examples of such a situation was the revitalization of post-industrial building at Tylna street in Łódź. Due to the change of use of the building for residential purposes replacement of wooden ceilings with reinforced concrete slab while maintaining the original layout of cast iron columns, was planned. In winter time, at temperatures of about $-20^{\circ} \mathrm{C}$, as recorded in 2013 , vertical cracks of a width up to several millimetres were noticed in some of the columns on the ground floor - see Figures $9 \mathrm{a}$ and $\mathrm{b}$. The width of the largest cracks reached about $7 \mathrm{~mm}$ - see Fig 9c. These cracks resulted from action of the mixture of water, oil and cement paste which froze and increased its volume inside the columns. The oil was a remnant from the period of functioning of the spinning mill, while water got inside the columns probably during the demolition works and casting of the floor slab. The contractor undertook an attempt to repair the damage by welding the vertical cracks. However, because the cause of the cracks was not removed, new cracks soon appeared, in the vicinity of previously welded joints.

After an unsuccessful attempt to repair, expert advice was sought. In places of cracks, the introduction of steel clamps, welded with single- $\mathrm{V}$ joint has been proposed. In order to ensure good adjacency of the rings to the column during the welding, temporary clamps with a flexible washer were used. The number of rings was selected individually depending on the extent of cracks.

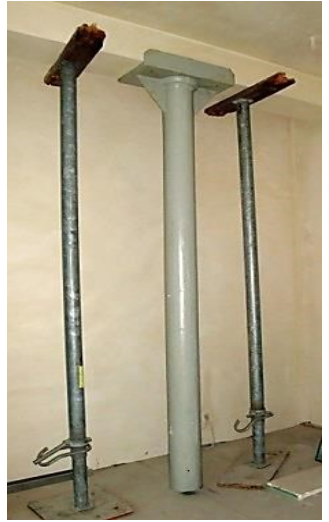

a)

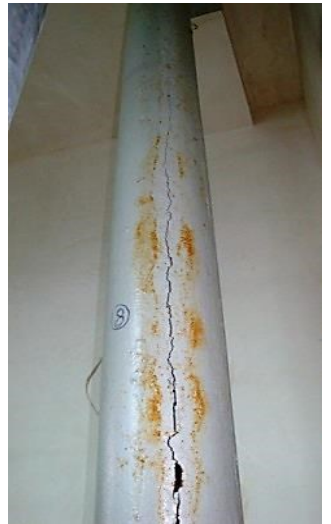

b)

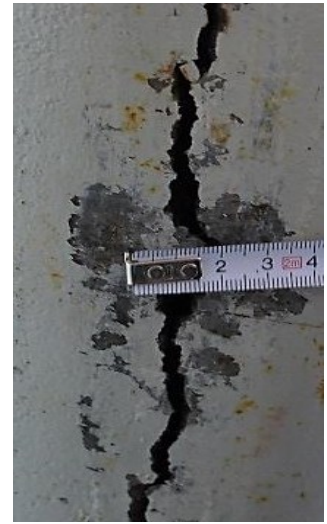

c)

Fig. 9. A view of the one of damaged columns on the ground floor of a revitalized building: a) a view of the temporary props, b) the vertical crack, c) width of the largest crack. 
A very serious failure of cast iron columns took place also in December 2009 in Wrocław. As part of works related to the modernization of viaducts within the active railway line, the decision was made to strengthen the Hartung columns (Hartungsche Säule) - pinned-pinned columns constituting the span supports - see Fig. 10a. According to the original assumptions of detailed design, cast iron columns were to be strengthened by filling them with a coarse aggregate concrete mix, while the defects occurred after casting concrete were to be filled with epoxy resin. This kind of strengthening was previously used in Germany, where over 300 columns were successfully strengthened [6]. The high effectiveness of strengthening by filling cast iron columns with a concrete mix was also confirmed by the results of experimental investigations carried out at the Berlin University of Technology on elements taken from the S-Bahn city rail overpasses. As was reported in [7], the load capacity of columns was increased from 16 to $19 \%$, while the deformation was reduced by $15 \div 35 \%$.

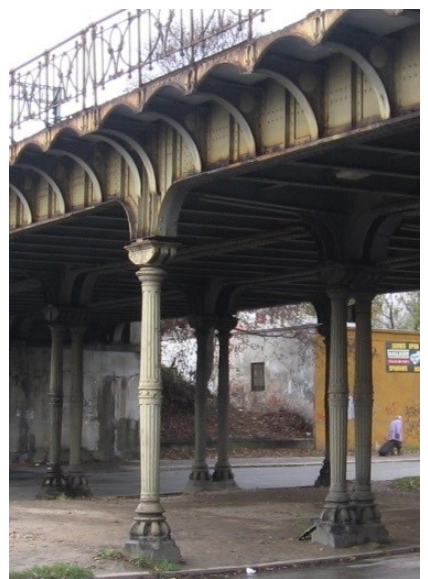

a)

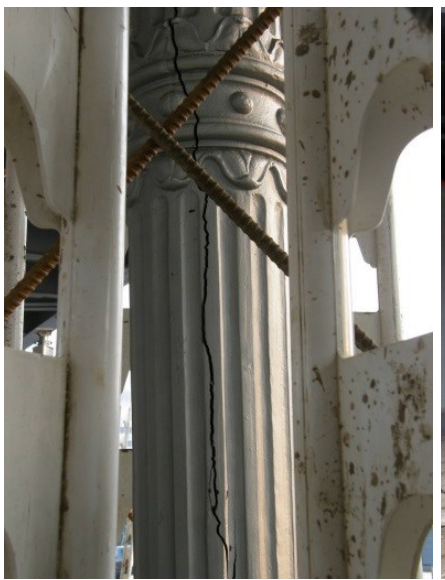

b)

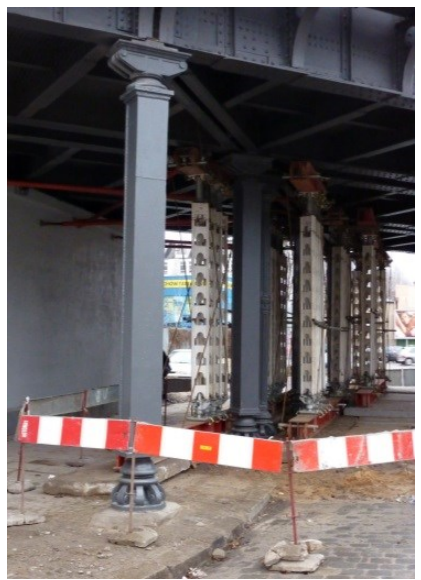

c)

Fig. 10. Supports of the railway flyover in Wrocław: a) before modernization works, b) after damage by freezing water, c) during replacement with new steel elements.

The strengthening carried out in Wrocław was however unsuccessful. This resulted from changes in the type of mixture as well as the replacement of an epoxy resin with a polyurethane resin, requiring the use of water to wet the substrate. Unfortunately, the above changes in combination with a significant drop in air temperature to several degrees below zero resulted in the damage of several columns - see Fig. 10b. The vertical cracks were the result of bursting by the water inside the columns. After several days, at the beginning of the thaw water began to flow out of from the cracks.

This failure caused significant difficulties in rail traffic, because it required temporary shutoff of the viaduct and the introduction of temporary supports - see Fig. 10c. One of the considered methods of repair was the use of carbon fibre wraps. Such a strengthening method was considered in experimental investigations of Marcinowski and Różycki [8]. They considered four cast iron columns subjected to eccentric compression. Two of them were wrapped with carbon textile. By using CFRP jacket the increase of the destructive force of about $70 \%$ was obtained. Ultimately however, the contractor replaced in Wrocław all of the cast iron columns (also the undamaged) for steel, with the shape corresponding to the original one. 


\section{Summary}

Examples of successful revitalization of post-industrial buildings demonstrate that cast iron columns can be successfully applied as load-bearing elements of structures used today. Experimental research carried out in laboratories in Vienna $[9,10]$ and in Łódź showed that the actual load carrying capacity of cast iron columns may exceed several times the values resulting from the 20th century design rules. The conservatism of the design principles resulted, however, from the material uncertainties - lack of homogeneity and hidden defects of the cast iron. The failure mode which is rapid, non-signalized and brittle should also be taken into account by assessing the load capacity of the existing cast iron columns.

\section{References}

1. PN-EN 1561:2012: Founding - Grey cast irons

2. K. Czapliński, Dawne wyroby ze stopów żelaza (Dolnośląskie Wydawnictwo Edukacyjne, Wrocław, 2009) [in Polish]

3. L. Tetmajer, Die Angewandte Elastizitäts- und Festigkeitslehre, (Franz Deuticke, Leipzig und Wien, 1905) [in German]

4. DIN 1051, Berechnungsgrundlagen für Gusseisen im Hochbau, (Berlin, 1937) [in German]

5. Österreich-ungarischer Bauratgeber-Bauindustrielles Handbuch. 2 Auflage, (Verlag von Moritz Perles, Wien, 1914) [in German]

6. K. Czapliński, K. Gawron, Przegląd Budowlany, 4, pp. 56-59 (2011) [in Polish]

7. S. Heyde, Nachweisverfahren für historische Stützen aus Grauguss, (Doctoral Disseration, Technische Universität Berlin, 2008) [in German]

8. J. Marcinowski, Z. Różycki, Civ. Envion. Eng. Rep., 1(20), pp. 37-45 (2016)

9. Untersuchungsbericht über Gusssäulen MA39 - VFA 2007-1038.01, (Magistrat der Stadt Wien Magistratsabteilung 39 Prüf-, Überwachungs- und Zertifizierungsstelle der Stadt Wien VFA - Labors für Bautechnik, 2007) [in German]

10. T. Urban, Przegląd Budowlany, 2, pp. 52-56 (2012) [in Polish] 